\title{
TOXICITY TESTS FOR ENSURING SUCCESFUL INDUSTRIAL WASTEWATER TREATMENT PLANT OPERATION
}

\section{TOKSICITĀTES TESTU IZMANTOŠANA RŪPNIECISKO NOTEKŪDEN̦U ATTĪRĪŠANAS IEKĀRTU SEKMĪGAS DARBĪBAS NODROŠINĀŠANAI}

B. Cēbere, Mg.Sc.biol., PhD student.

Riga Technical University, Institute of Energy Systems and Environment

Kronvalda boulevard 1, LV 1010, Riga, Latvia

Phone: +3717323210

e-mail: beata.cebere@rtu.lv

E. Faltiņa, B.Sc.

Riga Technical University, Laboratory of Environmental Technology Āzenes street 14, LV 1048 Riga, Latvia

Phone: +3716089265

e-mail: Elina.Faltina@rtu.lv

N. Zelčāns, M.Sc.

JSC “Grindeks", Active Pharmaceutical Ingredients Business Unit

Krustpils street 53, LV-1057

Phone: +371 67083219

e-mail: Normunds.Zelcans@grindeks.1v

D. Kalnin̦a, Dr.Chem.

Riga Technical University, Laboratory of Environmental Technology

Āzenes street 14, LV 1048 Riga, Latvia

Phone: +3716089265

e-mail: daina.kalnina@,rtu.lv 
Keywords: bioluminescence methods, respirometry methods, toxicity tests, wastewater bioassesment

\section{Introduction}

Effluent discharges from many industrial facilities are complex, comprising different components which vary in quantity and quality, and also can be polluted by toxic or non-biodegradable organic compounds [1]. Wastewater borne toxic chemicals may cause disease for aquatic organisms and generally are a serious threat to the environment. Different industries can pollute the environment, but residual pollutants [1] from the pharmaceutical industry can have a negative impact on biological systems. Pharmaceuticals can also contaminate water with detrimental effects on aquatic organisms and possibly human health [2].

As in a big industrial plant, it is difficult to trace the treatment loss, which can extend for months before normal operation can be recovered [3]. Toxicants can accumulate in the produced sludge, causing health risks for the plant operators [4]. The lack of treatment effectiveness could, in case of unexpected toxic influents to waste water treatment plants, lead to discharge of toxic and undegradable effluents into receiving waters. Chemical analysis alone cannot provide sufficient information on the potential harmful effects of chemicals on the aquatic environment [5]. A complete evaluation of wastewaters supplementing the chemical characterization therefore should include ecotoxicological tests as well, especially when concerned with complex wastewaters [6].

In many countries' jurisdiction, toxicology tests are introduced, as a lot of national and international organizations have standardized methods for ecotoxicity tests. Biological testing is now also rapidly expanding involving many bioanalytical techniques that are being developed and applied to organisms at different levels [5].

Toxicity characterization would be needed both for influents and effluents of a wastewater treatment plant and in such a way ecotoxicity tests are a useful tool for the identification of environmental impacts, and also could be useful as a tool for screening toxicity to avoid the disruption of activated sludge processes in order to protect biological treatment plants from toxic influents and to monitor the effectiveness of wastewater treatment plants.

This article gives an overview of the literature search results we obtained by focusing on the selection that is more promising and suitable aquatic toxicology test for sewage treatment plant influent toxicity monitoring.

\section{Importance of ecotoxicity in evaluation of wastewaters and trophic levels}

The early approach for wastewater analysis and monitoring for toxicity was on a chemical-specific basis. However the chemical specific approach alone has many shortcomings [4]. The measurement of COD and BOD are time consuming and inadequate for continuous monitoring of the wastewater quality. The toxic effects of unknown substances in complex mixtures or with possible synergistic effects can be detected only by toxicity testing [5]. At the same time, little is known about the potential interactive effects in the complex mixtures themselves [7].

In the United Kingdom Direct Toxicity Assessment programme [8] it was also found the limited assessment of toxicity by chemical effluents since in. $70 \%$ of screened effluents were found instances of effluents to be toxic to aquatic organisms even if all the effluents tested were compliant with their current discharge license conditions [9]. Ecotoxicity tests include the evaluation of the synergistic, antagonistic and additive affects of all the chemical, physical and biological components, which may adversely affect the physiological and biological functions of the test organism [10].

A variety of types of organisms representing different trophic levels and many different genera and species have been used for aquatic toxicity testing. The most 
commonly used tests include examples of plant, invertebrate and fish species in order to determine effects at various trophic levels [6], [7].

For the purpose of screening biological wastewater treatment influent, toxicity to activated sludge microorganisms is important. In this case, the toxicity data specific to activated sludge microorganisms are more important than the general toxicity data like toxicity to higher life forms [11]. However, for example, some widely used non-ionic surfactants are degraded by activated sludge microorganisms, but in this way a range of intermediate products which are formed can affect further fish, mammals and other organisms [12], [13]. In such a way an impact of disposed effluents in nature should take into account further evaluations, and the best way would be to include tests with different species and organisms, as each one may have a different sensibility. The environmental toxicity system ideally should consist of a primary producer (e.g. an alga), a primary consumer (e.g. aquatic arthropod), a secondary consumer (e.g. fish) and perhaps a tertiary consumer (e.g. a bird) in order to represent a typical aquatic system [10]. This approach is especially important since in biological testing it is known that organisms within the same and different trophic levels respond differently to a range of toxicants, both a single or complex mixture and there is therefore a need to develop toxicity bioassays using a suite of organisms [13].

Some species are most often used in ecotoxicity testing like Daphnia magna, fish tests, algal tests, Vibrio fisheri tests [14]. From these fresh water crustacean Daphnia magna is the species most used in the world for toxicity testing [15] and widely used in aquatic toxicology to assess the adverse effects of individual substances or complex mixtures. Testing is typically carried out according to internationally standardized protocols, however, according to this test the results cannot be interpreted for other organisms [ISO 6341:1996/Cor1:1998].

Microbial bioassays for toxicity detection offers many advantages over other bioassays, since they are functional and can represent and mimic higher organisms so as to allow better understanding of the effects on an ecosystem. Microbial tests are also inexpensive and less time consuming compared with complex toxicity tests involving higher organisms [9].

Also recently, phytotoxicity tests have become more popular. The freshwater algal species most frequently used are green microalga, Selenastrum capricornutum, and also Chlorella vulgaris. The use of algae in ecotoxicity tests has several advantages since they belong to the first level of the trophic chain, so any disturbance can affect the ecosystem at its higher levels, the algae are also very sensitive in regard to changes in the environment. Chlorella vulgaris has especially good sensitivity to toxicants and this alga is also easily cultured in the laboratory and is considered economical [10].

\section{Ecotoxicity tests in different countries, legislation backgrounds and standard testing}

Nowadays, national and regional authorities use ecotoxicity tests to meet various regulatory and legislative requirements [7].

The situation is more complicated because it is not known what substances industrial wastewater contain. Chemical analysis gives information about hazardous substances in water if they are used as individual substances. However, as a rule, wastewaters from the manufacturing process produce parent compounds, byproducts, different metabolites and their mutual interaction products. This is the reason why a simplified toxicological approach is not useful for the evaluation of pharmaceutical wastewaters.

However, bio-assessment does not provide information on the reason for the toxicity. As many as 100 compounds could be the source of the toxicity and it is important to assess exactly which compounds could damage the active sludge.

According to the EU Water Framework Directive and subsequent updating, 2006/11/EC [17] and 2008/32/EC [18], all water bodies must be protected and preserved. In order to improve water quality and guarantee the survival of species of aquatic organisms, the biodiversity of ecosystems should be protected and therefore quality concerning the ecotoxicological characteristics is required [10]. For countries to comply with good ecological status under the European Community Directive 2000/60/EC, the ecotoxicity of effluents is important [6]. In many countries ecotoxicity tests are already used in wastewater management.

The traditional way of identifying the toxic elements is to conduct a Toxicity Identification Evaluation (TIE) which is a procedure set out by the Environment Agency of England and Wales (EA) for identifying the substance(s) responsible for the toxicity of complex samples [7].

A number of countries are evaluating the use of aquatic toxicology testing under different names (WET (Whole effluent toxicity) in USA, DTA (Direct Toxicity Assessment) in UK etc.). WET testing has been in use for effluent and receiving water quality in the USA since the 1940's. The purpose of WET is to identify, characterize and eliminate the toxic effects of discharges on aquatic resources. WET has been also used in Australia as part of an ecological and human risk assessment in support of regulatory requirements [7].

DTA, the UK terminology for WET is seen as a third component in an integrated approach to water quality 
management, complementing the existing elements of substance specific control and biological assessment.

There is also increasing interest in the WET approach in Europe with Germany and Sweden having the most experience and the Netherlands committed to WET development work and trial. WET is likely to play an important role in the implementation of legislation such as the Integrated Pollution Prevention and Control (IPPC) Directive and the proposed EU Water Framework Directive.

In Germany toxicity tests are used in conjunction with chemical parameters for the regulation of a number of different industries under the Federal Water Act, the Wastewater Ordinance and the Wastewater Charges Act. Tests specified within legislation include fish, Daphnia, luminescent bacteria and algae. Ecotoxicological testing of industrial wastewater has been used for more than 20 years in Denmark.

Also, according to Greek legislation, there is no obligation to test the effluents of wastewater treatment plants with bioassays in Greece [14]. The situation is similar in Latvia. Nonetheless some enterprises have introduced ecotoxicity tests such as in Olainfarm where the company is growing Daphnia magna and testing effluents with them.

Various organizations have developed standard test methods for acute and chronic aquatic testing including Organization for Economic Cooperation and Development (OECD), the United States Environmental Protection Agency (USEPA), the American Society for Testing and Materials (ASTM) and the American Public Health Association (APHA). EU countries mainly used methods proposed by ISO, but the OECD proposed to implement both standard and national methods. ISO acute toxicity standards are similar to the OECD guidelines [19].

\section{Toxicity tests to activated sludge}

One of the tasks of ecotoxicity tests would be to protect the treatment plant from the shock of incoming polluted toxic wastewaters.

For treating industrial wastewaters, the activated sludge process (ASP) is that which is most used [20], [21]. Toxicants in ASP influent can cause disturbance to the operations of ASP. These upsets could be a decrease in waste organics removal, reduction of solids separation efficiency and modification of sludge. Such upsets can be avoided if ASP influent wastewater is screened for toxicity and protective actions are taken.

Based on the organisms and processes in ASPmicroorganisms, toxicology tests which are used for monitoring of influent to WWTP according to Ren [21] could be grouped in the following way:

1) Bioluminescence methods;

2) Respirometry methods;
3) Nitrification/denitrification inhibition assays;

4) Molecular-based assays and sensors.

The most widely used and studied biotests for wastewater toxicity evaluation for aerobic treatment are bioluminescence and respirometric methods as they are practical and have the biggest significance of screening the toxicity of wastewater treatment plants. The biotests for wastewater treatment plant influent also need to exhibit rapid detection because these tests would be needed not only for detection but also for preventive actions [9].

Bioluminescence methods.Bioluminescence has been widely used in toxicity tests [9]. For wastewater toxicity evaluation, the most thoroughly investigated test system is the Microtox assay [21], and it is reported as one of the most commonly applied. The Microtox assay is based on naturally occurring luminescent marine bacterium Vibrio fischeri, which possesses a constitutive promoter controlling the luxCDABE cassette that encodes for enzymes that catalyze lightproducing reactions [21], [22]. This test is also a standard ecotoxicological bioassay in Europe (DIN EN ISO 11348). It is a very rapid, cost-effective and widely-accepted method for toxicity determination [15]. $V$. fisheri is also often used to compare various microbial bioassays [13].

The natural bioluminescent bacteria however, can be particularly sensitive to some industrial wastewater and therefore their response to normal operational conditions does not reflect the status of the microbial community responsible for treatment [23], [24]. Tzoris [9] also reports that $V$.fischeri assay is not ideal for monitoring influent wastewater toxicity.

Organisms isolated from activated sludge are more resistant to wastewater toxicants and can respond to the appearance of a toxicant. On this basis Ren and Frymier, 2003 developed a continuous wastewater toxicity testing system using the luminescent bacterium Shk1 (genetically modified organism) carrying the luxCDABE operon of $V$.fischeri. It was found that Shk1 assay is less sensitive than the Microtox assay and could be more suitable for influent wastewater toxicity monitoring [21], [25]. However there may be a question as to whether genetically modified bacteria would be accepted by environmental agencies [24].

Philp et al [17] has tested the system as a biosensor using natural and genetically modified bioluminescent bacteria and have found that an immobilization system and a modified bioluminescent Pseudomonad performed to expectations with pure toxicants phenol and 3-chlorophenol.

Enzymes can be used as test systems instead of organisms to evaluate the potential hazard of contaminants in wastewater or river water. Thus in the study by Gagne [12], the toxicity of industrial wastewaters were evaluated with a very rapid and 
sensitive chemiluminescent peroxides assay-based on the peroxidase -catalyzed oxidation of luminal by hydrogen peroxide. It is responsive to the presence of radical scavengers and the assay is rapid. It was found that this assay complied relatively well $(60 \%)$ with Microtox assay, suggesting that the light inhibiting effects of the effluent correspond to toxic effects in bacteria. This assay may be used for prescreening studies when the number of test samples is very high.

Respirometry methods. Compared to bioluminescence methods, activated sludge respirometry is a more direct method for assessing sludge activity and toxicity to sludge [26]. Many activated sludge respirometric methods are well established and standardized tests have existed for a long time (e.g. Organization for Economic Cooperation and Development (OECD), 1984; USA Environmental Protection Agency (EPA), 1966; and International Organization for Standardization (ISO), 1966. The approach in these tests is based on Oxygen Uptake Rate (OUR) testing to determine the basic cause for inhibition of microbiological respiration rate. These methods are easy, fast and inexpensive compared to other approaches.

Respirometry has been used extensively for decades. Literature describes the use of biosensors, assays and respirometers for this toxicology testing method. As has been described, the biosensor for wastewater toxicity is based on inhibition of the respiration of oxygensensitive bacteria (strain unspecified) isolated from activated sludge [12], [26].

There has been described the use of biosensor CellSense (Euroclone, Pero, Italy) for organic toxicants in wastewater. In this study the immobilized E.coli cells were used, though other options of sensor organisms are possible. In the biosensor, the resultant electric signal was an indicator of bacterial respiratory activity [26]; [27].

In the other sludge respirometry-based assay using well microplates the respiration was indirectly quantified, the color being the indicator of sludge respiration [26], [28].

In the activated sludge respiration inhibition assays conducted by Pernetti et al [23], [26] the organic carbon removal by sludge was monitored, in addition to measuring the specific oxygen uptake rate.

The combined use of an activated sludge respirometer with a titrimetric technique has been used for activated sludge monitoring. Inclusion of titration to respirometry provided additional information about the carbon source [26], [29].

Using the principle of respirometry installed instrumentation is functioning in the sewerage authority of Thessaloniki [14]. When there is inhibition in the oxygen, the uptake rate is higher than a preset value and an alarm is activated and wastewater can be diverted to a calamity basin. In this way the toxic shock of the activated sludge microorganisms can be prevented.

Comparative studies. Many reports and publications have been done on comparison of different bioassays. Like in Dalzell et al. study [13], five rapid direct toxicity assessment methods -nitrification inhibition, respirometry, adenosine triphosphate luminescence and enzyme inhibition were tested. It was found that the $V$. fischeri test was more sensitive compared to the tests using activated sludge. It was recommended also by this study that at least two of the toxicological tests utilizing activated sludge should be used to reduce the possibility of missing a particular toxic effect.

Girotti [24] reports that $V$. fisheri is the most sensitive compared to other bacterial bioassays such a nitrification inhibition, respirometry, ATP luminescence and enzyme inhibition. Several studies are reporting and have found out that $V$.fisheri is more sensitive than activated sludge respirometry [9].

Also different commercial systems based on the bioluminescent bacterium $V$. fisheri are compared. In a study by Jennings [30] commercial assay systems ToxAlert $10 \AA$, Microtox ${ }^{\circledR}$ and LUMIStox ${ }^{\circledR}$ have been compared. It was found out determined that these assays show very similar results and there is no significant difference.

The study by Mendonca [7] has evaluated the sensitivity of different tests and the following gradient of test sensitivity has been detected: Microto $x$ Thamnotox $<$ Daphnia $=$ AlgalTox $>$ Lemna.

\section{Conclusions}

The whole effluent testing is increasing rapidly as a cost-effective means of evaluating and controlling the environmental impact of such emissions. Toxicity tests are especially important in pharmaceutical production as there are a lot of changes, the flow is in batch mode and very often it is even difficult to say what products are forming in the chemical process not to mention the possible impact to microorganisms.

Data in literature shows that some invertebrate and fish assays that are commonly used in aquatic toxicology are not suitable for sewage treatment plant influent toxicity monitoring. The best correlations between toxicity tests and the actual behavior of an activated sludge plant can be obtained when microorganisms from the particular activated sludge plant themselves are used in toxicity tests. The results of bioassay should be directly extrapolated to predict the toxicity effect to microorganisms in the bioreactor. Different ecotoxicity tests are used in order to detect the toxicity of activated sludge. The respirometry methods seem to be very valuable. As an advantage these methods are not difficult, easily implemented and inexpensive. 
As an additional tool the ecotoxicity tests would be needed in order to determine the necessity for the pretreatment of industrial wastewaters already near the production.

In many countries biotesting is developed and is required by law. In Latvia, chemical monitoring is conducted for evaluation of the wastewater. Ecotoxicity is only a little developed but it would be a future direction in the evaluation of wastewaters, especially of complicated industrial ones. Bioassays would be a significant tool, especially for the evaluation of industrial wastewaters in order to protect the biological treatment plant from toxic shock and also to avoid the release of toxic substances into the environment.

\section{References}

1. Sirtori C.,Zapata A., Oller I. Gernjak W., Aguera A., Malato, S. Decontamination industrial pharmaceutical wastewater by combining solar photo-Fenton and biological treatment // Water research. - 43 (2009), P.661-688.

2. Kümmerer $K$. The presence of pharmaceuticals in the environment due to human use-present knowledge and future challenges // Journal of Environmental Management. - 8 (2009), P.23542366.

3. Philp J.C., Balmand S., Hajto E., Bailey M.J., Wiles, S., Whiteley A.S., Lilley A.K., Hajto J., Dunbar S.A. Whole cell immobilised biosensors for toxicity assessment of a wastewater treatment plant treating phenolics-containing waste // Analytica Chimica Acta. - 487 (2003), P. 61-74.

4. Caffaro-Filho R.A., Morita M. D., Wagner R., Durrant L.R. Toxicity-directed approach of polyester manufacturing industry wastewater provides useful information for conducting treatability studies // Journal of Hazardous Materials. - 163 (2008), P.92-97.

5. Sponza D. T. Toxicity studies in a chemical dye production industry in Turkey // Journal of Hazardous Materials. - A138 (2006), P.438-447.

6. Mitchell Ed.J.A.K., Burgess J.E., Stuetz R.M. Developments in ecotoxicity testing // Reviews in Environmental Science and Biotechnology. - 1 (2002), P.169-198.

7. Mendonca E., Picado A., Paixao S.M., Silva L., Cunha M.A., Leitao S., Moura I., Cortez C.,Fatima $\mathrm{Br}$. Ecotoxicity tests in the environmental analysis of wastewater treatment plants: Case study in Portugal // Journal of Hazardous Materials. - 2-3 (2009), P.665-670.

8. Tinsley D., Wharfe J., Campbell D., Chown Ph., Taylor D., Upton J., Taylor C. The Use of direct toxicity assessment and control of complex effluents in the UK: a demonstration programme // Ecotoxicology. - 13 (2004), P.423-436.

9. Tzoris A., Hall E.A.H. Rapid detection of toxicity in wastewater: Recent development with manometric respirometry // Analytica Chimica Acta. - 573-574 (2006), P.147-157.

10. Silva A., Figueiredo S.A., Sales G.M., Matos C.D. Ecotoxicity tests using the green algae Chlorella vulgaris- A useful tool in hazardous effluent management // Journal of Hazardous Materials. - ( 2009), Article in Press, Corrected Proof.

11. Ren S., Frymier P.D. Estimating the toxicities of organic chemicals to bioluminescent bacteria and activated sludge // Water research. - 17 (2002), P.4406-4414.

12. Servos M.R. Review of the aquatic toxicity, estrogenic responses and bioaccumulation of alkylphenols and alkylphenol polyethoxylates // Water Quality Research Journal of Canada. - 34 (1999), P.123-177.

13. Dalzell D.J.B., Alte S., Aspichueta E., de la Sota A., Etxebarria J., Gutierrez M., Hoffmann C.C., Sales D., Obst U., Christofi N. A. Comparison of five rapid toxicity assessment methods to determine toxicity of pollutants to activated sludge // Chemosphere. - 47 (2001), P.535-545.

14. Toxicity characterization of influents and effluents in a wastewater treatment plant / Balkan Cooperation Network, 1998. http://library.certh.gr/libfiles/PDF/SAK-BALKANCOOPNTWRK-THESS-Y1998-PP175-180.pdf.

15. Immich A.P.S., Ulson de Souza A.A., Ulson de Souza de Arruda Guelli S.M. Removal of remazol Blue RR dye from aqueous solutions with Neem leaves and evaluation of their acute toxicity with Daphnia magna // Journal of Hazardous Materials. - 2-3 (2009), P.1580-1585.

16. Picado A., Chankova A., Fernandes A., Simoes F.,Leverett D., Johnson I., Hernan R., Pires M.A., Matos J. Genetic variability in Daphnia magna and ecotoxicological evaluation // Ecotoxicology and Environmental Safety. - 3 (2007), P.406-410.

17. European Community. Directive 2006/11/EC of the European Parliament and of the Council on pollution caused by certain dangerous substances discharged into the aquatic environment of the Community // Official Journal of the European Communities. -23.10 .2000 .

18. European Community. Directive 2008/32/EC of the European Parliament and of the Council amending Directive 2000/60/EC establishing a framework for Community action in the field of water policy, as regards the implementing powers conferred on the Commission // Official Journal of the European Communities. - 11.03.2008.

19. Vosiliene M.Z. Review of the methods for acute and chronic toxicity assessment of single 
substances, effluents and industrial waters // Acta Zoologica Lithuanica. - 1 (2007), P.1392-1657.

20. Wong K.Y., Zhang M.Q., Li X.M., Lo W.A. A luminescence -based scanning respirometer for heavy metal toxicity monitoring // Biosensors and Bioelectronics. - 12 (1997), P.125-133.

21. Romero A., Santos A., Tojo J.,Rogriguez A. Toxicity and biodegradibility of imidazolium ionic liquids // Journal of Hazardous Materials. - 1 (2007), P.268-273.

22. Hastings J.W., Nealson K.H. Bacterial luminescence // Annual Review of Microbiology. 31(1977), P.549-595.

23. Pernetti M., Di Palma Li., Merli C. A real time toxicity bioassay for activated sludge reactor // International Journal of Chemical Reactor Engineering. - 1 (2003), P.1-11.

24. Girotti S., Ferri E.N., Fumo M.G., Maiolini E. Monitoring of environmental pollutants by bioluminescent bacteria // Analytica Chimica Acta. - 1 (2008), P.2-29.

25. Ren S., Frymier P.D. The use of a genetically engineered Pseudomonas species (Shk1) as a bioluminescent reporter for heavy metal toxicity screening in wastewater treatment plant in wastewater treatment plant influent // Water Environment Research. - 75 (2003), P.21-29.

26. Ren S. Assessing wastewater toxicity to activated sludge: recent research and developments // Environment International. - 8 (2004), P.11511164.

27. Farre M., Passini O., Alonso M.C., Castillo M., Barcelo D. Toxicity assessment of organic pollution in wastewaters using a bacterial biosensor // Analytica Chimica Acta. - 426 (2001), P.155-165.

28. Freitas dos Santos L.F., Defrenne L., Krebx-Brown A. Comparison of three microbial assay procedures for measuring of toxicity of chemical compounds: Toxalert ${ }^{\circledR}$ 10, Cell Sense and Biolog MT2 microplates // Analytica Chimica Acta 456 (2002), P.41-54.

29. Gernaey A.K., Petersein B., Ottoy J.-P., Vanrolleghem P. Acivated sludge monitoring with combined respirometric -titrimetric measurements // Water Research. - 35(2001), P.103-110.

30. Jennings K.L.V., Rayner-Brandes M.H., Bird D.J. Assessing chemical toxicity with the bioluminescent photobacterium (Vibrio fischeri) - a comparison of three commercial systems // Water research. - 14 (2001), P.3448-3456.
Beata Cēbere, Elīna Faltiṇa, Normunds Zelčāns, Daina Kalniņa, Toksicitātes testu izmantošana rūpniecisko notekūdeņu attīrī̌anas iekārtu sekmīgas darbības nodrošināšanai

Rūpnieciskie notekūdeņi ir sarežğìti un var būt piesārņoti ar nebiodegradabliem un toksiskiem organiskajiem savienojumiem, kas var būt drauds apkārtējai videi. Ķ̄̄miskās analīzes nevar dot pietiekamu informāciju par ūdeņu piesārņojumu raksturu. Piln̄̄gai notekūdeņu izvērtēšanai ir jāietver arī ekotoksikologiskie testi, īpaši svarīgi tas ir kompleksiem notekūdeñiem. Mūsu literatūras izpētē mèginājā̄m noteikt, kas ir piemērotākā ūdens toksikoloğijas metode notekūdeņu attīrī̌sanas iekārtu ieplūdes toksicitātes monitoringam. Pētījumā aprakstīti dažādi organismu veidi, kas pārstāv dažādus trofiskos līmeņus un daudzas dažādas sugas, kuras tiek izmantotas ūdens toksicitātes testos. Toksicitātes raksturojums ir nepieciešams gan ieplūstošiem, gan izplūstošiem notekūdeñiem no attīì̌šanas iekārtām. Lai pārbaudītu biologisko attīrīšanas iekārtu ieplūdi, ir svarīgi izmantot toksicitātes testos aktīvo dūņu mikroorganismus. Plašāk izmantotie toksikologiskie testi ir respirometrija un bioluminescences toksikologijas testi. Respirometrijas toksicitātes testi ir viegli, ātri un arī nav dārgi, salīdzinot ar citām pieejām. Arī bioluminescence ir plaši izplatīta un visvairāk šeit izmantotā testa sistēma ir Microtox. Veikta toksicitātes testu salīdzināšana. Starptautiskās, nacionālās un regionālās varas iestādes izmanto šos testus, lai sasniegtu dažādus regulatoros un likumdošanas mērķus. Biotestēšanas nozīme ir arī uzsvērta ES likumdošanā.

Beata Cebere, Elina Faltina, Normunds Zelcans, Daina Kalnina, Toxicity tests for ensuring successful industrial wastewater treatment plant operation

Industrial wastewaters are complex and can be polluted by non-biodegradable end toxic organic compounds and are a serious threat to the environment. Chemical procedure alone cannot provide sufficient information. A complete evaluation of wastewaters should include ecotoxicological tests too, 
especially concerning the complex wastewaters. In the literature review the authors attempted to establish which is the more promising and suitable aquatic toxicology test for sewage treatment plant influent toxicity monitoring.

$A$ variety of types of organisms representing different trophic levels and many different species are used for aquatic toxicity testing. Toxicity characterization would be needed both for influents and effluents of wastewater treatment plant. For the purpose of screening biological wastewater treatment influent, toxicity to activated sludge microorganisms is important and toxicology tests here used are respirometry and bioluminescence toxicology tests. Respirometry toxicity tests are easy, fast and inexpensive compared to other approaches. Bioluminescence has been widely used, the most thoroughly investigated test system is the Microtox. The toxicity tests have also been compared by different authors. International, national and regional authorities use these tools to meet various regulatory and legislative requirements. Importance of biotesting has been emphasized also in EU legislation.

Бэата Цебере, Элина Фалтиня, Нормундс Зелчанс, Даина Калниня, Использование тестов токсичности для обеспечения успешной работы очистных установок для очистки промышленных сточных вод

Промышленные сточные воды сложные и могут быть загрязнены небиодеградируемыми и токсичными органическими соединениями, которые могут быть угрозой для окружающей среды. Химические анализы не могут дать достаточную информацию о характере загрязнения вод. Для полного анализа сточных вод нужно использовать экотоксикологические тесты, это особенно важно для комплексных сточных вод. Проводя исследования литературь мы пробовали определить самый подходящий метод определения токсичности воды очистных сооружений для мониторинга токсичности входящего потока. $B$ исследовании описаны разные типь организмов, которые представляют разные трофические уровни и разные виды, которые используются в токсикологических mестах воды. Токсикологическая характеристика необходима как втекаемым, так и вытекаемым из очистных сооружений сточнымм водам. Чтобы проверить впуск сооружений биологической очистки, в токсикологических тестах важно использовать микроорганизмы активного ила. Респирометрия и токсикологические тесты биолюминесиенции являются наиболее широко используемыми токсикологическими тестами. Токсикологические тесты респирометрии простые, быстрые, а также недорогие в сравнении с другими способами. Биолюминесценщия также широко распространена, больще всего используемая тестовая система Microtox. Было проведено сравнение токсикологических тестов. Международные, национальные и региональные учреждения используют эти тесты, чтобы достичь разные регуляторные и законодательные цели. Значение биотестирования подчёркнуто в законодательстве EC. 